\title{
Use of indocyanine green dye clearance in a patient with liver cirrhosis undergoing hepatectomy: a clinical image
}

\author{
Laurence Weinberg, ${ }^{1}$ Callum Robinson, ${ }^{1}$ Su Kah Goh, ${ }^{2}$ Vijayragavan Muralidharan ${ }^{3}$
}

'Department of Anaesthesia, Austin Health, Heidelberg, Victoria, Australia

${ }^{2}$ Translational Genomics and Epigenomics Laboratory, Olivia Newton-John Cancer Centre at Austin Health, Heidelberg Victoria, Australia

${ }^{3}$ Surgery, Austin Health, University of Melbourne, Melbourne, Victoria, Australia

\section{Correspondence to} Associate Professor Laurence Weinberg, laurence.weinberg@austin. org.au

Accepted 7 June 2018

\section{Check for updates}

(C) BMJ Publishing Group Limited 2018. No commercial re-use. See rights and permissions. Published by BMJ.

To cite: Weinberg $L$, Robinson C, Goh SK, et al. BMJ Case Rep Published Online First: [please include Day Month Year]. doi:10.1136/bcr-2018225503

\section{DESCRIPTION}

Indocyanine green (ICG) is a water-soluble, non-toxic tricarbocyanine dye extracted exclusively from the hepatic parenchyma. Measurement of ICG clearance using pulse spectrophotometry is a simple, reproducible and non-invasive test, easily performed in the operating room. ICG plasma disappearance rate (PDR) and the retention rate at $15 \mathrm{~min}$ (R15) produce real-time metrics to aid assessment and decision-making before, during and after complex liver surgery. ICG clearance has also been used to suggest the presence of postoperative complications, including thrombosis of the hepatic artery and graft dysfunction following liver transplantation. We present a case of 65-year-old Caucasian man, with Child-Pugh A liver cirrhosis undergoing complex right hepatectomy for metastatic colorectal liver cancer where ICG clearance impacted on the extent of surgical resection.

Given the concerns about marginal postoperative liver function of the residual left hepatic lobe, we used pulse spectrometry intraoperatively to predict the risk of postoperative liver dysfunction. Immediately preoperatively, a dose of $20 \mathrm{mg}(0.25 \mathrm{mg} / \mathrm{kg})$ ICG dye was dissolved in $20 \mathrm{~mL}$ of distilled water (figure 1) and injected into the right internal jugular vein through a central venous catheter, over a 3 s period. PDR and R15 were recorded with a LiMON-Technology device (Pulsion Medical System SE, Germany) and automatically calculated in accordance with the time course of the blood ICG concentration. The PDR was $19.8 \% / \mathrm{min}$ and the R15 was $6.7 \%$, quantitatively reflecting normal parenchymal function. Intraoperatively, after dissection of the portal vessels, we applied selective arterial and venous inflow trial clamping to the right portal vein and hepatic artery. A further dose of $20 \mathrm{mg}(0.25 \mathrm{mg} / \mathrm{kg})$ ICG dye was injected which demonstrated a PDR of $14.8 \% / \mathrm{min}$ and R15 of $10.9 \%$ (figure 2). This quantitatively reflected acceptable postoperative parenchymal functional reserve and flow conditions of the residual left liver lobe. ${ }^{12}$ The postoperative risk of liver dysfunction was considered adequate given the curative intent of the surgery. The patient underwent an uncomplicated right hepatectomy.

On postoperative day 1, ICG measurements were repeated, revealing clinically reassuring changes in ICG values compared with the intraoperative measurements. The PDR was $15.7 \% / \mathrm{min}$, and R15 was $8 \%$. Parenchymal enzymes aspartate transaminase (AST) and alanine transaminase (ALT) peaked on the third postoperative day (AST $260 \mathrm{IU} / \mathrm{mL}$; ALT 557 $\mathrm{IU} / \mathrm{mL}$ ), then returned abruptly to baseline values on

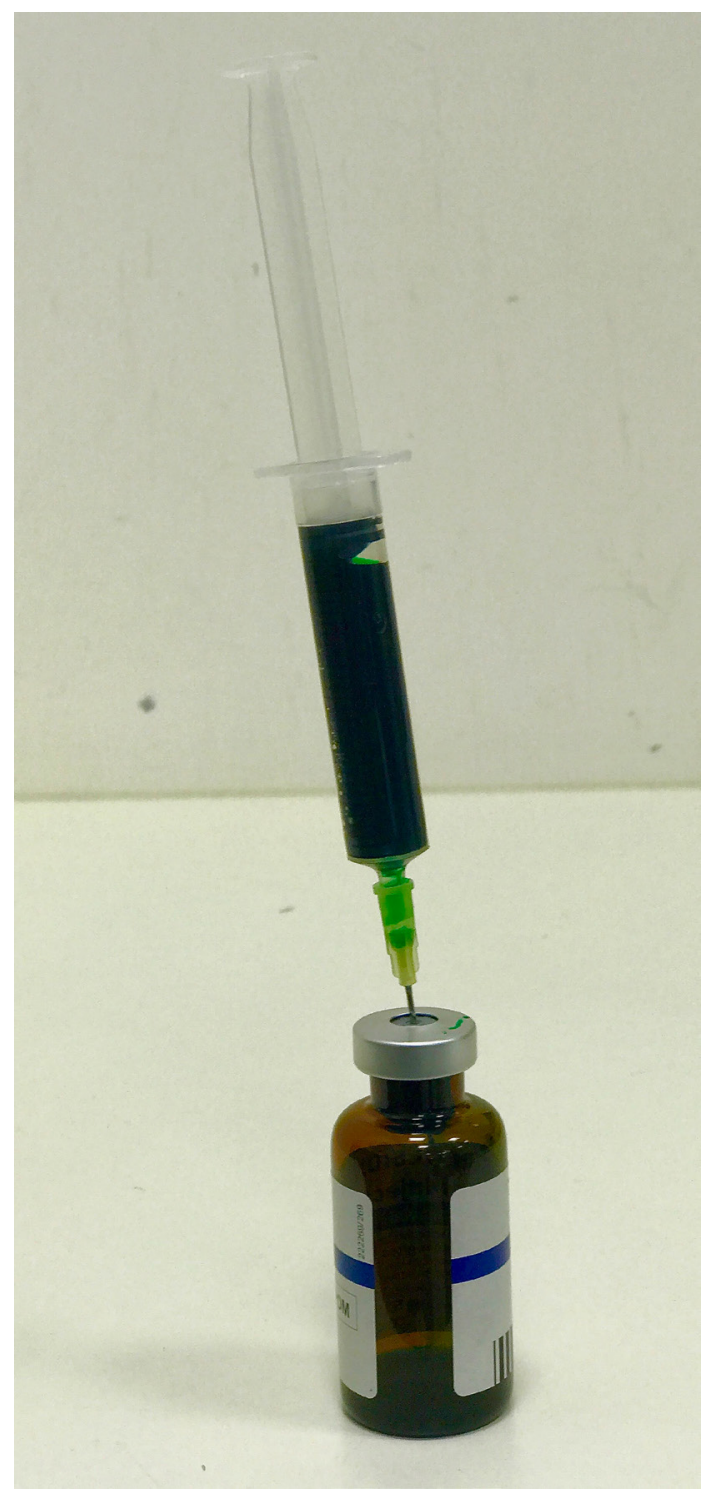

Figure 1 Preparation of indocyanine green for intravenous injection.

postoperative day 5 . Prothrombin time elevated within 48 hours postoperatively to a peak value of 17 seconds, normalising on postoperative day 4. Partial thromboplastin time and total serum bilirubin levels remained essentially normal throughout the entire postoperative course. Albumin fell to approximately 50\% of normal, gradually rising to near baseline values by postoperative day 6 . The patient made an uneventful recovery, except for developing a mild ileus, and was discharged home on postoperative day 7. 


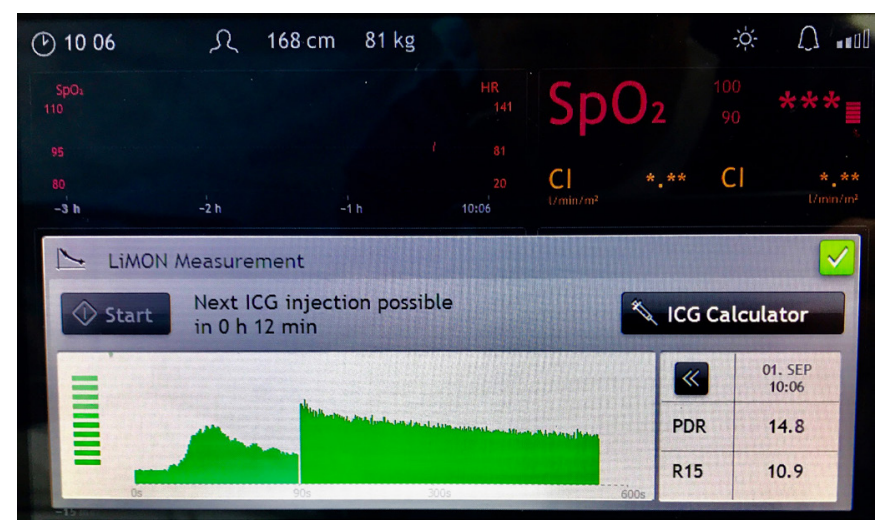

Figure 2 Trace of the concentration of indocyanine green (ICG) in the plasma over time. Displayed are the calculated plasma disappearance rate (PDR) and ICG retention at 15 min (R15) values. $\mathrm{Cl}$, cardiac index; $H R$, heart rate; $\mathrm{SpO2,} \mathrm{oxygen} \mathrm{saturation.}$

\section{Learning points}

- Indocyanine green (ICG) is a water-soluble, non-toxic tricarbocyanine dye extracted exclusively from the hepatic parenchyma.

- Change in concentration of ICG over time can be measured using non-invasive pulse dye densitometry.

- ICG clearance provides valuable dynamic information about liver function, predicting postoperative risk of liver dysfunction during and after liver resection and transplant surgery.
Our case highlights the clinical utility of using ICG testing to dynamically predict postoperative risk of liver dysfunction during major liver resection surgery in a patient with cirrhosis. The use of decisional algorithms based on ICG clearance to select liver resective procedures according to liver functional reserve should be considered in patients with cirrhosis who are being planned for minor or major liver resection surgery. ${ }^{1-3}$

Contributors LW was the principal anaesthetist who cared for the patient. He performed all the intraoperative indocyanine green (ICG) tests. He was responsible for the design and conception of the report. He helped perform the literature review, was the lead author and prepared the submission of this manuscript. VM was the principal surgeon managing the patient. He was involved in the conception and design of this clinical image and helped prepare the manuscript. SKG was the surgical assistant involved in this case. He helped perform the ICG testing in theatre, and was responsible for the assisting with the literature review and the writing of the manuscript. CR helped perform the literature review, prepare the images and assisted in the writing of the manuscript.

Funding The authors have not declared a specific grant for this research from any funding agency in the public, commercial or not-for-profit sectors.

Competing interests None declared.

\section{Patient consent Obtained.}

Provenance and peer review Not commissioned; externally peer reviewed.

\section{REFERENCES}

1 De Gasperi A, Mazza E, Prosperi M. Indocyanine green kinetics to assess liver function: ready for a clinical dynamic assessment in major liver surgery? World J Hepatol 2016;8:355-67.

2 Haegele S, Reiter S, Wanek D, et al. Perioperative non-invasive indocyanine greenclearance testing to predict postoperative outcome after liver resection. PLoS One 2016;11:e0165481.

3 Thomas MN, Weninger $E_{\text {, Angele }} \mathrm{M}$, et al. Intraoperative simulation of remnant liver function during anatomic liver resection with indocyanine green clearance (LiMON) measurements. HPB 2015;17:471-6.

Copyright 2018 BMJ Publishing Group. All rights reserved. For permission to reuse any of this content visit http://group.bmj.com/group/rights-licensing/permissions.

BMJ Case Report Fellows may re-use this article for personal use and teaching without any further permission.

Become a Fellow of BMJ Case Reports today and you can:

- Submit as many cases as you like

- Enjoy fast sympathetic peer review and rapid publication of accepted articles

- Access all the published articles

- Re-use any of the published material for personal use and teaching without further permission

For information on Institutional Fellowships contact consortiasales@bmjgroup.com

Visit casereports.bmj.com for more articles like this and to become a Fellow 